\section{У.В. Омеляш}

Львівський національний медичний університет ім. Данила Галицького

Надійшла: 16.08 .2018

Прийнята: 18.09 .2018
DOI: https://doi.org/10.26641/1997-9665.2018.3.99-104

УДК: 616.441-089-06:616.441-002-036.112-091.8 ПІДГОСТРИЙ ТИРЕОЇДИТ ДЕ КЕРВЕНА: КЛІНІКО-ПАТОМОРФОЛОГІЧНІ ОСОБЛИВОСТІ У ОПЕРОВАНИХ 3 ПРИВОДУ ЗАХВОРЮВАНЬ ЩИТОПОДІБНОЇ ЗАЛОЗИ

Дослідження проведено в рамках науково-дослідної теми «Вивчення патоморфологічних особливостей захворювань щитоподібної залози, сериево-судинної, травної, сечовидільної та репродуктивної систем і перинатального періоду з метою удосконалення їх морфологічної діагностики» (номер державної реєстраиії 0118000100).

() Morphologia. - 2018. - T. 12, № 3. - C. 99-104.

(C) У.В. Омеляш (ORCID: 0000-0003-1027-2141), 2018

\ulyanaomelyash@ukr.net

Omelyash U.V. Subacute de Quervain's thyroiditis: clinical and pathomorphological features of patients operated on thyroid gland.

ABSTRACT. Background. An annual increase in the number of patients with endocrine pathology is observed in Ukraine. Subacute de Quervain's thyroiditis is a rare inflammatory disease of thyroid gland of viral etiology which on average occurs in 3 - 6\% of cases among all thyroid pathology. Objective - to study clinical and pathomorphological features of Subacute de Quervain's thyroiditis of patients operated on thyroid gland in the last ten years. Methods. Analysis of archival data results of pathohistological reports on the patients operated on thyroid gland in Lviv Regional Clinical Hospital in 2006-2015 and medical histories with diagnosed cases of Subacute de Quervain's thyroiditis was conducted. In ten years' time 5587 cases of patients operated on thyroid gland pathology have been revealed, among them 17 cases of Subacute de Quervain's thyroiditis which is $0,3 \%$ from all thyroid diseases. There were only women among the patients and their average age was 56 . Results. While studying the medical histories it was revealed that the most frequent women's complaints were the following: feeling of a foreign body in the neck area, discomfort when swallowing, bulging on the front of the neck, dyspnea, general weakness. Subacute de Quervain's thyroiditis was not diagnosed clinically in any case, and in one third of the cases there was a suspicion of malignant thyroid tumor. Pathoanatomical diagnosis in half of the cases was combined and often Subacute de Quervain's thyroiditis was combined with a multi-nodule colloid goiter. Conclusion. Subacute de Quervain's thyroiditis is a rare pathology of thyroid gland without sufficiently characteristic pathognomonic signs that makes clinical diagnostics rather difficult. Thoroughly collected anamnesis and conducting of appropriate laboratory tests including ultrasonic diagnostics of thyroid gland help to diagnose Subacute de Quervain's thyroiditis.

Key words: Subacute de Quervain's thyroiditis, thyroid gland.

\title{
Citation:
}

Omelyash UV. [Subacute de Quervain's thyroiditis: clinical and pathomorphological features of patients operated on thyroid gland]. Morphologia. 2018;12(3):99-104. Ukrainian.

DOI: https://doi.org/10.26641/1997-9665.2018.3.99-104.

\section{Вступ}

Кількість хворих з ендокринною патологією в Україні щорічно збільшується, зокрема з 2005 по 2011 роки приріст становив 9,85\% [1].

Підгострий тиреоїдит де Кервена (ТК) - запальне захворювання щитоподібної залози (ЩЗ) вірусної етіології [2-7]. ТК відноситься до рідкісної патології ЩЗ. Підтверджено, що дане захворювання Щ3 розвивається через кілька тижнів після перенесеної вірусної інфекції. Найчастіше діагностується у жінок молодого та середнього віку, дуже рідко виникає у чоловіків та практич- но не виникає у дітей $[2,6,8]$.

Вперше ТК описав швейцарський хірург де Кервен у 1904 році (de Quervain Fritz, 1868-1940). Інша назва ТК - гранулематозний зоб де Кервена, гранулематозний гігантоклітинний тиреоїдит $[8,9]$.

За різними літературними даними, частка ТК серед усієї тиреоїдної патології становить 3 $6 \%$ випадків [8].

За даними Nicolai T.F. (1991), один випадок ТК припадає на 5 випадків дифузного токсичного зоба або на 20 випадків хронічного автоімун- 
ного тиреоїдиту Хашімото [5].

Захворювання починається гостро 3 підвищення температури тіла (до субфебрильних або фебрильних цифр), загальної слабості, болю в ділянці шиї з можливою іррадіацією в нижню щелепу, вухо, що посилюється при нахилі голови чи поворотах шиї, можлива дисфагія $[2,3,8]$. При ТК ЩЗ збільшена дифузно або вогнищево, асиметрична. Пальпаторно відмічається ущільнення ЩЗ з нечіткими контурами або у вигляді вузлів, що чутливі при пальпації $[2-4,6,8]$. При проведенні ультразвукового дослідження виявляють наявність гіпоехогенних або анехогенних структур у вигляді вузлів чи ділянок з нечіткими, неоднорідними контурами $[8,10,11]$. Внаслідок дії вірусів на тканину залози, відбувається руйнування фолікулів та поступлення гормонів ЩЗ (тироксину, трийодтироніну) у кров, що зумовлює зменшення утворення тиреотропного гормону. Клінічно це проявляється тиреотоксикозом. В подальшому, коли припиняється надходження гормонів ЩЗ із зруйнованих фолікулів і в залежності від кількості зруйнованих тиреоцитів, виникає еутиреоїдний або гіпотиреоїдний стан [2, $3,5,8]$. Також характерним $є$ прискорене ШОЕ 3 нормальним показником кількості лейкоцитів, рідко з незначним збільшенням кількості нейтрофілів [4, 7]. Диференційну діагностику ТК проводять 3 іншими захворюваннями ЩЗ та нетиреоїдними захворюваннями: гострим тиреоїдитом, аутоімунним тиреоїдитом Хашімото, дифузним токсичним зобом, раком ЩЗ, флегмоною шиї, отитом, фарингітом, синдромом скронево- нижньощелепного суглоба.

Лікування пацієнтів з ТК - симптоматичне. Одужання пацієнтів може бути і спонтанним після кількох тижнів або місяців $[8,12]$. Прогноз у хворих сприятливий, проте ТК може рецидивувати $[6,12]$.

Метою роботи було вивчення клінікопатоморфологічних особливостей підгострого тиреоїдиту де Кервена у оперованих з приводу захворювань Щ3 за 2006-2015 роки.

\section{Матеріали та методи}

Опрацьовано архівні дані патогістологічних заключень Львівського обласного патологоанатомічного бюро хворих, оперованих з приводу захворювань ЩЗ у Львівській обласній клінічній лікарні за 10 років (2006-2015 рр.) За досліджуваний період було виявлено 17 випадків ТК. Проаналізовано всі 17 історій хвороб з діагнозами ТК в архіві Львівської обласної клінічної лікарні.

\section{Результати та їх обговорення}

Виявлено 5587 випадків оперованих пацієнтів з приводу тиреоїдної патології, з них 17 випадків ТК, що становить 0,3 \% від всіх захворювань ЩЗ за десять років.

Найбільша кількість випадків з ТК було діагностовано у 2011 році, що становить 0,8 \% випадків серед оперованих з приводу захворювань Щ3 (рис. 1). Це могло бути пов'язано з почастішанням вірусних інфекцій в даному році. Оскільки, відомо, що розвиток ТК пов'язують з перенесеними вірусними інфекціями.

Відсотки

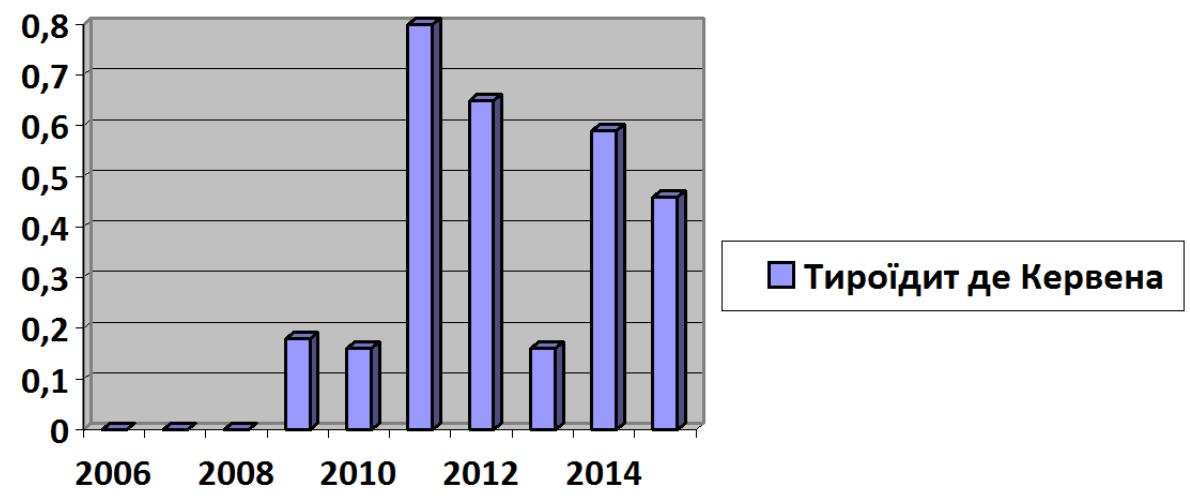

Роки

Рис. 1. Частка хворих з тиреоїдитом де Кервена серед загального числа оперованих з приводу захворювань щитоподібної залози з 2006 по 2015 роки.

Усі хворі з діагностованим ТК були виключно жінки. Наймолодший вік пацієнтки 3 даною патологією Щ3 - 35 років, а найстаршій пацієнтці було 73 роки. Середній вік пацієнток - 56 років.

Клінічно ТК у всіх випадках не був діагностований. У 15 випадках клінічний діагноз був багатовузловий колоїдний зоб, у п'яти 3 них він був поєднаний з раком ЩЗ. В одному випадку клінічний діагноз був - автоімунний тиреоїдит та ще в одному - рак ЩЗ. Тобто майже в третині випадків була підозра на злоякісну пухлину ЩЗ.

Цікавим є факт, що жодного разу в клінічному діагнозі не було вказано чи запідозрено ТК, що наштовхує на думку, що дана патологія $\epsilon$ важкою для клінічної діагностики.

При опрацюванні вибраних 17 історій хвороб виявлено, що найчастіше пацієнти скаржи- 
лись на: відчуття стороннього тіла в ділянці шиї $(\mathrm{N}=13)$, дискомфорт при ковтанні $(\mathrm{N}=8)$, вип'ячення на передній поверхні шиї $(\mathrm{N}=2)$, загальну слабість $(\mathrm{N}=4$, задишку $(\mathrm{N}=3)$, в одному випадку у пацієнтки не було скарг $(\mathrm{N}=1)$.

В одному випадку в анамнезі хвороби було вказано, що пацієнтка перенесла ГРВІ два тижні тому. В дев'яти випадках пацієнтки до моменту звернення протягом $1-13$ років хворіли зобом, в одному випадку вузол був виявлений при профілактичному огляді за тиждень до поступлення в стаціонар, у шести випадках вузол виявляли від кількох тижнів до шести місяців до моменту поступлення в стаціонар. Відповідно, коли пацієнти зверталися в хірургічне відділення то, ймовірно, у стадії еутиреозу. Тому характерних лабораторних показників, як таких, що підтверджують діагноз ТК, не було виявлено. Наприклад, ШОЕ могло бути різко прискорене, як у тих пацієнтів, що хворіють потягом місяця, так і в тих, що хворіють протягом декількох років. Цей показник коливався в межах від 5 мм/год до 46 мм/год. При визначенні рівнів гормонів картина аналогічна: тиреотропний гормон (ТТГ), тироксин (Т4), трийодтиронін (Т3), рівень антитіл до тироїдної пероксидази (Ат до ПО) та до тиреоглобуліну (Ат до ТГ) коливався в різних межах і не завжди їх рівень підтверджував діагноз ТК, вірогідно тому, що пацієнти зверталися вже у стадії еутиреозу або гіпотиреозу. (табл. 1). В багатьох випадках рівні гормонів не визначали або визначали не всі показники гормонів. Один випадок був класичний - пацієнтка мала знижений рівень ТТГ і підвищений рівень Т4 та Т3.

Таблиця 1 Показники рівнів гормонів у пацієнтів, оперованих з приводу захворювань щитоподібної залози за період з 2006 по 2015 роки, з патологоанатомічним діагнозом тиреоїдит де Кервена

\begin{tabular}{|c|c|c|c|c|}
\hline \multirow[b]{2}{*}{ Гормони } & \multicolumn{4}{|c|}{ Рівень гормонів (абс. к-сть випадків) } \\
\hline & Норма & $\begin{array}{l}\text { Вище } \\
\text { норми }\end{array}$ & $\begin{array}{l}\text { Нижче } \\
\text { норми }\end{array}$ & $\begin{array}{c}\text { Не визна- } \\
\text { чали }\end{array}$ \\
\hline ТТГ & 6 & 1 & 6 & 4 \\
\hline $\mathrm{T} 4$ & 5 & 1 & - & 11 \\
\hline T3 & 2 & 2 & - & 13 \\
\hline $\mathrm{T} \Gamma$ & 6 & 1 & - & 10 \\
\hline $\begin{array}{ll}\text { Ат } & \text { до } \\
\text { ПО } & \end{array}$ & 7 & - & - & 10 \\
\hline $\begin{array}{l}\text { Ат } \\
\text { доТТГ }\end{array}$ & 3 & - & - & 14 \\
\hline
\end{tabular}

При огляді Щ3 була збільшена дифузно або вогнищево за рахунок однісї частки - 41 \% випадків, за рахунок збільшення обох часток ЩЗ - у 24 \% випадків, у 35 \% випадків при огляді Щ3 не контурувалась.

При ультразвуковому дослідженні візуалізовувались найчастіше гіпоехогенні вузли різних розмірів.

При макроскопічному дослідженні операційного матеріалу тканини ЩЗ виявляли такі зміни: наявність вузла або декількох вузлів білосірого кольору, щільної консистенції, розміром від 0,3 до 2,5 см або/та ділянки білої щільної тканини 3 нечіткими контурами, діаметром від 0,3 до 4 см.

При мікроскопічному дослідженні тканини Щ3 виявляли: ділянки пошкодження тиреоїдних фолікулів з формуванням структур, подібних на гігантські багатоядерні клітини (рис. 2), помірно виражений склероз, дифузну або вогнищеву інфільтрацію лімфоцитами, макрофагами, плазматичними клітинами те нейтрофільними лейкоцитами (рис. 3).

У двох випадках було проведено тонкоголкову пункційну аспіраційну біопсію (ТПАБ) вузла з наступним цитологічним дослідженням. Цитологічний висновок в обох випадках був однаковий: автоімунний тиреоїдит Хашімото та підозра на рак ЩЗ. В літературі знайдено подібне дослідження, де також з 17-ти випадків у двох було проведено ТПАБ, з подібними висновками, які не підтверджували ТК [13].

У чотирьох випадках $з$ 17-ти було проведено експрес діагностику тканини ЩЗ: у двох випадках патогістологічний висновок - ТК, в третьому - фолікулярна аденома, в четвертому - фолікулярна аденома та фокальний тиреоїдит.

Після патогістологічного дослідження операційного матеріалу патологоанатомічний діагноз у дев'яти випадках був комбінованим. У семи випадках він складався з двох патологій ЩЗ: в п'яти 3 них ТК поєднувався з багатовузловим колоїдним зобом, в одному випадку - 3 маленьким папілярним раком (що не був вказаний у клінічному діагнозі) та ще в одному - 3 аденомою Щ3. У двох випадках патологоанатомічний діагноз складався з трьох патологій ЩЗ, а саме: ТК, багатовузловий колоїдний зоб та фокальний тиреоїдит в одному випадку і ТК, багатовузловий колоїдний зоб та аденоліпома - в другому. Клінічний діагноз в останніх двох випадках був вказаний - багатовузловий колоїдний зоб з підозрою рак Щ3.

\section{Висновки}

1. Серед загального числа оперованих 3 приводу захворювань Щ3 за 2006-2015 роки ТК виявлено у $0,3 \%$ випадків. ТК діагностували лише у жінок, середній вік яких становив 56 років. У всіх випадках ТК клінічно не був діагностований. Переважно (у 15 випадказ з 17-ти) клінічно діагностували багатовузловий колоїдний зоб. В третині випадків підозрювали рак ЩЗ. Більше, ніж в половині випадків патологоанатомічний діагноз був комбінованим. При патогістологічному дослідженні найчастіше виявляли поєднання ТК з багатовузловим колоїдним зобом. 
2. Тиреоїдит де Кервена - рідкісна патологія ЩЗ, без достатньо характерних патогномонічних ознак, що значно ускладнює клінічну діагностику. Допомагає у встановленні діагнозу ретельно зібраний анамнез, а також проведення відповід- них лабораторних досліджень та УЗД ЩЗ. Своєчасна діагностика $є$ важливою для визначення тактики лікування. Захворювання потребує подальшого всебічного вивчення.

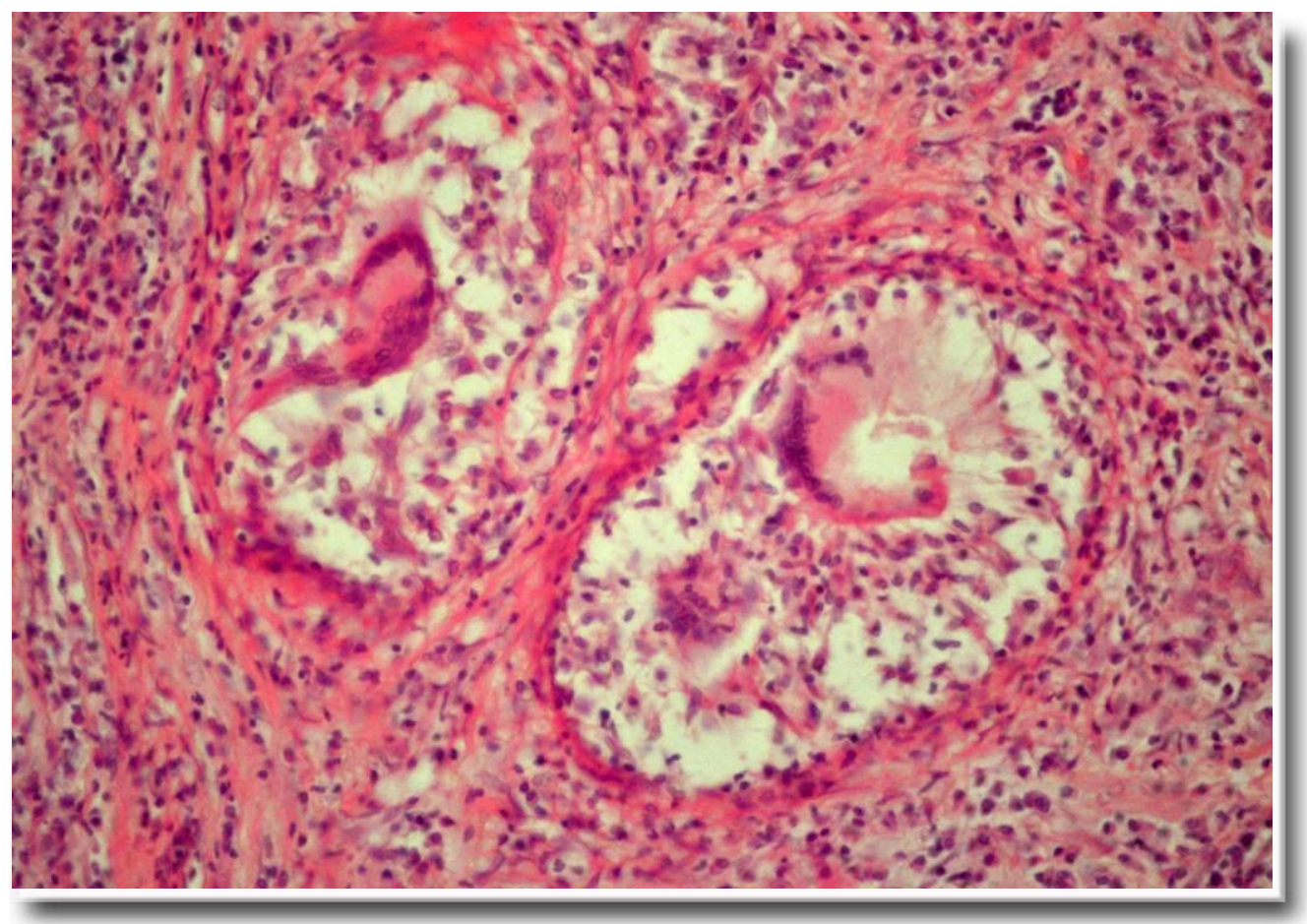

Рис. 2. Тиреоїдит де Кервена з ознаками пошкодження тиреоїдних фолікулів, формуванням структур, подібних на гігантські багатоядерні клітини, дифузна інфільтрація лімфоцитами. Забарвлено гематоксиліном та еозином. ×400.

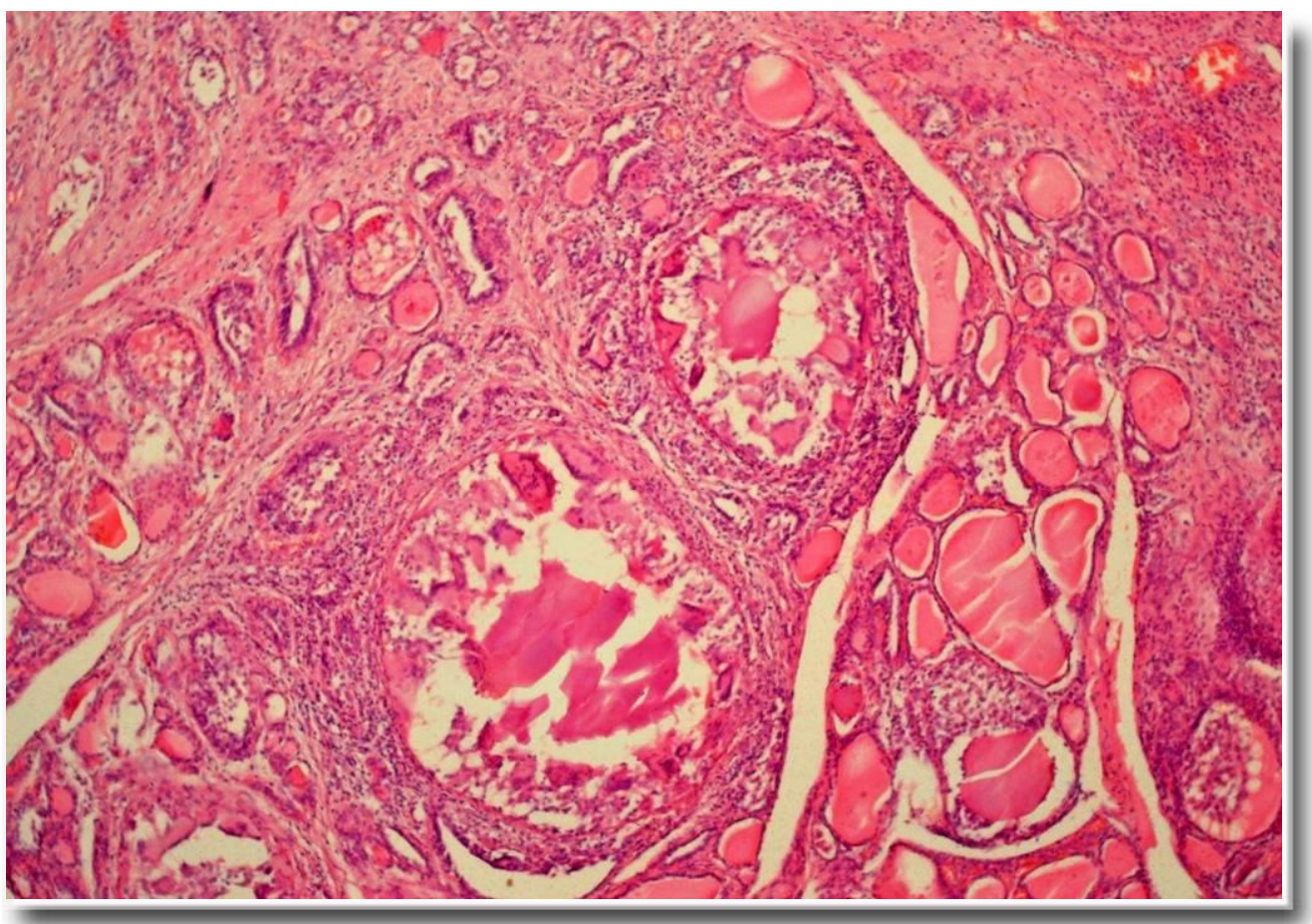

Рис. 3. Тиреоїдит де Кервена з ділянками склерозу, дифузною лімфоцитарною інфільтрацією, пошкодженими фолікулами та формуванням структур, подібних на гігантські багатоядерні клітини. Забарвлено гематоксиліном та еозином. $\times 100$. 


\section{Літературні джерела \\ References}

1. Larin OS. [Analysis of work of the endocrinology service of Ukraine in 1010 and the prospects for the development of medical care of patients with endocrine pathology]. International endocrinology journal. 2011;35(3):10-8. Ukrainian.

2. Alfadda AA, Sallam RM, Elawad GE, Aldhukair H, Alyahya MM. Subacute thyroiditis: Clinical presentation and long term outcome. Int J Endocrinol. 2014;2014:794-943.

3. Oláh R, Hajós P, Soós Z, Winkler G. De Quervain thyroiditis. Corner points of the diagnosis. 2014;155:676-80.

4. Frates MC, Marqusee E, Benson $\mathrm{CB}$, Alexander EK. Subacute Granulomatous (de Quervain) thyroiditis. Grayscale and color Doppler sonographic characteristics. J Ultrasound Med. 2013;32:505-11.

5. [Subacute thyroiditis (de Quervain's thyroiditis)]. Available from: http://www.dovidnyk.org/dir/2/5/50.html. - (date: 03.08.2018). Ukrainian.

6. Bindra A, Braunstein GD, Cedars-Sinai Medical Center. Thyroiditis. American Family Physician. 2006;73(10):1769-76.

7. Fatourechi V, Aniszewski JP, Guiti Z, Fatourechi E, Atkinson EJ, Jacobsen SJ. Clinical Features and Outcome of Subacute Thyroiditis in an Incidence Cohort: Olmsted County, Minnesota,
Study. The Journal of Clinical Endocrinology \& Metabolism. 2003;88(5):2100-5. doi:http://dx.doi.org/10.1210/jc.2002-021799.

8. Vural C, Paksoy N, Gök ND, Yazal K. Subacute granulomatous (De Quervain's) thyroiditis: Fine-needle aspiration cytology and ultrasonographic characteristics of 21 cases. Cyto Journal. 2015;12:9.

9. Bhadauria RS, Nema SK, Kumar P. De Quervain's Thyroiditis. Medical Journal Armed Forces India. 2003;59(4):347-8.

10. Cappelli C, Pirola I, Gandossi E, Formenti AM, Agosti B, Castellano M. Ultrasound findings of subacute thyroiditis: A single institution retrospective review. Acta Radiol. 2014;55:429-33.

11. Omori N, Omori K, Takano K. Association of the ultrasonographic findings of subacute thyroiditis with thyroid pain and laboratory findings. Endocr J. 2008;55:583-8.

12. Mordes DA, Brachtel EF. Cytopathology of subacute thyroiditis. Diagn Cytopathol. 2012;40:433-4.

13. Duininck TM, Heerden JA, Fatourechi V, Curlee KJ, Farley DR, Thompson GB, Grant CS, Lloyd RV. De Quevain's Thyroiditis: Surgical Experience. Endocrine Practice. 2002;8(4):255-8. https://doi.org/10.4158/EP.8.4.255.

Омеляш У.В. Підгострий тиреоїдит де Кервена: клініко-патоморфологічні особливості у оперованих з приводу захворювань щитоподібної залози.

РЕФЕРАТ. Актуальність. В Україні відзначається щорічний приріст кількості хворих 3 ендокринною патологією. Підгострий тиреоїдит де Кервена - рідкісне запальне захворювання щитоподібної залози (Щ3) вірусної етіології, який в середньому зустрічається в $3-6$ \% випадків серед усієї тиреоїдної патології. Мета роботи - вивчення клініко-патоморфологічних особливостей підгострого тиреоїдиту де Кервена у оперованих з приводу захворювань Щ3 за 2006-2015 роки. Проведено аналіз архівних даних результатів патогістологічних висновків хворих, оперованих з приводу захворювань ЩЗ у Львівській обласній клінічній лікарні за період 2006-2015 рр. та історії хвороб з виявленими випадками тиреоїдиту де Кервена. За десять років виявлено 5587 випадків оперованих пацієнтів 3 приводу тиреоїдної патології, 3 них 17 випадків ТК, що становить 0,3 \% від всіх захворювань ЩЗ. Серед пацієнтів були виключно жінки, середній вік яких - 56 років. При опрацюванні історій хвороб виявлено, що найчастішими скаргами пацієнток були: відчуття стороннього тіла в ділянці шиї, дискомфорт при ковтанні, вип’ячування на передній поверхні шиї, задишка, загальна слабість. Клінічно у всіх випадках тиреоїдит де Кервена не був діагностований, а в третині випадків була підозра на злоякісну пухлину ЩЗ. Патологоанатомічний діагноз в половині випадків був комбінованим і найчастіше тиреоїдит де Кервена поєднувався з багатовузловим колоїдним зобом. Висновки: тиреоїдит де Кервена - рідкісна патологія Щ3, без достатньо характерних патогномонічних ознак, що значно ускладнює клінічну діагностику. Допомагає у встановленні діагнозу ретельно зібраний анамнез та проведення відповідних лабораторних досліджень, а також ультразвукове дослідження ЩЗ.

Ключові слова: підгострий тиреоїдит де Кервена, щитоподібна залоза.

Омеляш У.В. Подострый тиреоидит де Кервена: клинико-патоморфологические особенности у оперированных по поводу заболеваний щитовидной железы.

РЕФЕРАТ. Актуальность. В Украине отмечается ежегодный прирост числа больных с эндокринной патологией. Подострый тиреоидит де Кервена - редкое воспалительное заболевание щитовидной 
железы (ЩЖ) вирусной этиологии, который в среднем встречается в 3 - 6\% случаев среди всей тиреоидной патологии. Цель работы - изучение клинико-патоморфологических особенностей подострого тиреоидита де Кервена у оперированных по поводу заболеваний щитовидной железы за 2006-2015 годы. Проведен анализ архивных данных результатов патогистологических выводов больных, оперированных по поводу заболеваний щитовидной железы в областной клинической больнице за период 2006-2015 гг. и истории болезней с выявленными случаями тиреоидита де Кервена. За десять лет выявлено 5587 случаев оперированных пациентов по поводу тиреоидной патологии, из них 17 случаев ТК, что составляет $0,3 \%$ от всех заболеваний щитовидной железы. Среди пациентов были исключительно женщины, средний возраст которых - 56 лет. Результаты. При обработке историй болезней обнаружено, что наиболее частыми жалобами пациенток были: ощущение инородного тела в области шеи, дискомфорт при глотании, выпячивание на передней поверхности шеи, одышка, общая слабость. Клинически во всех случаях тиреоидит де Кервена ни был диагностирован, а в трети случаев было подозрение на злокачественную опухоль щитовидной железы. Патологоанатомический диагноз в половине случаев был комбинированным и чаще всего тиреоидит де Кервена сочетался с многоузловым коллоидным зобом. Выводы: тиреоидит де Кервена - редкая патология щитовидной железы, без достаточно характерных патогномоничных признаков, что значительно усложняет клиническую диагностику. Помогает в установлении диагноза тщательно собранный анамнез и проведения соответствующих лабораторных исследований, а также ультразвуковое исследование ЩЖ.

Ключевые слова: подострый тиреоидит де Кервена, щитовидная железа. 